\title{
Unilateral blindness as a complication of nasal septoplasty: case report
}

\author{
Cegueira unilateral como complicaçãode septoplastia nasal: relato decaso
}

\author{
Mário Luiz Ribeiro Monteiro ${ }^{1}$
}

Trabalho realizado na Divisão de Clínica Oftalmológica do Hospital das Clínicas da Faculdade de Medicina da Universidade de São Paulo - USP - São Paulo (SP) Brasil.

${ }^{1}$ Professor of Ophthalmology of the Department of Ophthalmology and Otolaryngology. Hospital das Clínicas da Faculdade de Medicina - Universidade de São Paulo - USP - São Paulo (SP) - Brasil.

Correspondence address: Mário Luiz R. Monteiro - Av. Angélica 1757 conj. 61 - São Paulo (SP) CEP 01227-200 E-mail: mlrmonteiro@terra.com.br

Recebido para publicação em 30.03.2005

Versão revisada recebida em 17.06.2005

Aprovação em 16.11.2005

\begin{tabular}{l} 
ABSTRACT \\
\hline Blindness as a complication of nasal septoplasty is a devastating occurrence \\
with only a few cases reported in the literature. In most of these cases, \\
visual loss was attributed to retinal embolism following intra-arterial \\
injection of substances into the nasal turbinate. This paper documents one \\
case of complete unilateral blindness from direct optic nerve trauma \\
following an apparently uneventful septorhinoplasty. Ophthalmologists \\
and otolaryngologists should therefore be aware of the possible occurrence \\
of such complication.
\end{tabular}

Keywords: Blindness/etiology; Rhinoplasty/adverse effects; Optic nerve/injury; Postoperative complications; Visual loss; Case reports [publication type]

\section{INTRODUCTION}

Blindness following a minor operative procedure can be a devastating complication for both the patient and surgeon. Very few cases of visual loss following septorhinoplasty, a simple and frequently performed operation for the correction of nasal septum deviations have been reported ${ }^{(1-3)}$. In most of these cases, visual loss was attributed to retinal embolism following the retrograde flow of an intra-arterial injection of substances into the turbinates. We report a patient who lost all vision in one eye during such a procedure as a result of direct trauma to the optic nerve in the orbital apex.

\section{CASE REPORT}

A 28-year-old woman was admitted for elective surgical correction of a marked leftward deflection of the nasal septum. Under general anesthesia, the mucous membrane on both sides of the nasal septum was elevated and parts of both the cartilaginous and bony septum were removed. The operation was described as routine and uneventful.

Upon awakening the following day the patient noticed that she could not see with the left eye (OS). An ophthalmic examination revealed a visual acuity of 20/20 in the right eye (OD) and no light perception in OS. There was a slight left lid edema and a small hematoma in the medial portion of the inferior eyelid. There was no proptosis. Pupils were equal in size but there was no direct reaction to light in the left one. Ophthalmoscopy and the rest of the ophthalmic examination were normal in both eyes.

A computerized tomography scan revealed multiple fractures of the left medial orbital wall, including one near the optic canal (Figure 1). Treatment with high doses of intravenous corticosteroids was initiated and two days later an optic canal decompression was performed through frontal cranioto- 


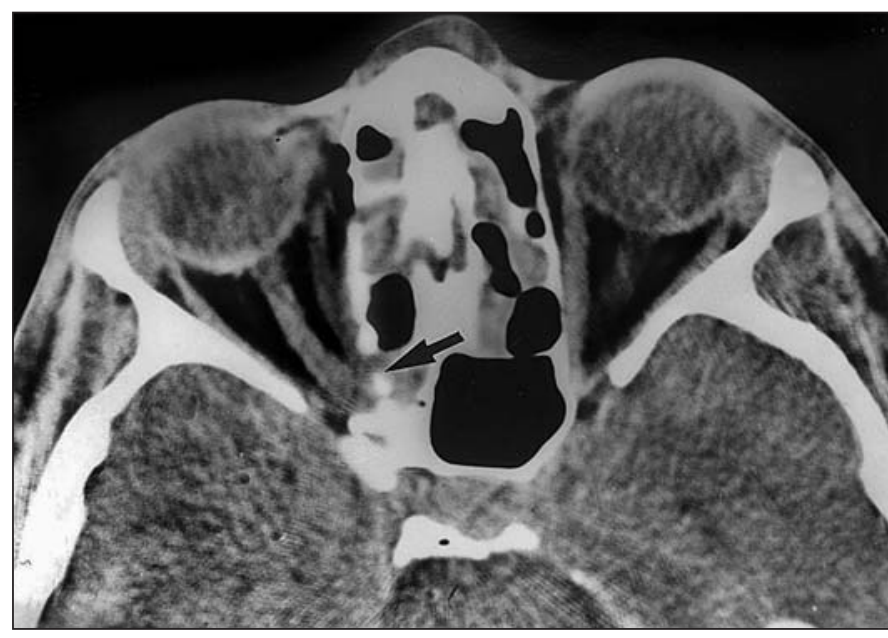

Figure 1 - Computerized tomography scan showing fractures of the left medial orbital wall near the optic canal (arrow)

my. During surgery, when viewed from above the optic nerve appeared normal and without any evidence of hematoma. However, a direct visualization of the inferior and nasal aspects of the nerve was not possible. Vision did not improve after surgery and total optic nerve atrophy developed two months later in OS.

\section{DISCUSSION}

While visual loss is a known complication of ethmoidectomies it seems to be very unusual following nasal surgery, since I have been unable to find more than a few publications on the subject. In 1981, two authors reported three patients who had visual loss in one eye after submucous resection of the nasal septum ${ }^{(1)}$. Two patients had partial visual loss. Because in these patients there were no signs of other cranial nerve palsies, the authors believed that direct trauma was unlikely and that the visual loss might have resulted from a vascular disturbance in the optic nerve. They suggested that a high pressure intra-arterial injection of local anesthetics in combination with adrenalin in the mucosa during surgery could have led to retrograde flow into branches of the ophthalmic artery with subsequent occlusion of the feeding vessels of the optic nerve. Some authors have reported similar cases in which the mechanism responsible for visual loss was a central retinal artery occlusion following injection of local anesthetics into the nasal mucosa during elective septorhinoplasty $^{(2-3)}$. One author reported a patient with temporary visual loss after an injection of anesthetics into the nasal mucosa ${ }^{(4)}$.

Direct trauma to the optic nerve, however, is another, apparently rare mechanism of visual loss in nasal rhinoseptoplasty. The third patient reported by two authors ${ }^{(1)}$ had total visual loss associated with a sixth nerve palsy and $\mathrm{X}$-ray evidence of blurring of the ethmoidal cells and of the maxillary sinus on the same side. In this case, direct trauma was the suspected mechanism. To my knowledge the present case is the first in which direct trauma to the optic nerve after submucous resection of the nasal septum was confirmed by computerized tomography scan. This case shows that direct optic nerve injury can be an isolated complication of an apparently uneventful surgery. Although not observed by the surgeon, the instrument used to fracture the bony part of the septum may have been placed too high and too laterally in the posterior nasal cavity reaching the optic canal area. The potential for such an occurrence is significant since in many cases the anatomy of the posterior and higher portion of the nasal cavity is somewhat distorted due to a preexistent septum abnormality. The scarcity of reports on the subject indicates that the occurrence is either very rare or underreported. However, considering the medical and legal implications they may come to cope with, ophthalmologists and otolaryngologists should be aware of the possible occurrence of such complications.

\section{RESUMO}

Cegueira como complicação de septoplastia nasal é uma ocorrência devastadora com apenas poucos casos relatados na literatura. Na maioria destes casos, a perda visual foi atribuída a embolismo retiniano após injeção intra-arterial de substâncias no corneto nasal. Este trabalho documenta um caso de cegueira unilateral completa decorrente de trauma direto do nervo óptico durante uma septorrinoplastia aparentemente sem intercorrências. Oftalmologistas e otorrinolaringologistas devem portanto estar cientes da possibilidade da ocorrência desta complicação.

Descritores: Cegueira/etiologia; Rinoplastia/efeitos adversos: Nervo óptico/lesões: Complicações pós-operatórias; Perda visual; Relatos de casos [tipo de publicação]

\section{REFERENCES}

1. Plate S, Asboe S. Blindness as a complication of rhinosurgery. J Laryngol Otol. 1981;95(3):317-22.

2. Cheney ML, Blair PA. Blindness as a complication of rhinoplasty. Arch Otolaryngol Head Neck Surg. 1987;113(7):768-9.

3. Gomes CC, Sakano E, Lucchezi MC, Panhoca R, Melo RRG, Abreu M. Perda da visão unilateral pós-septoplastia. Rev Bras Otorrinolaringol. 1993;59:142-5.

4. Wind J. Blindness as a complication of rhinoplasty. Arch Otolaryngol Head Neck Surg. 1988;114(5):581. 